\title{
The Cost Implications of Primary School Educational Policy Shift Toward Free Education at Point of Delivery for Primary School Children: The Case Study of Nyamagana District
}

\author{
Paul Charles Kamani* Chen Yinghua* Pakmoni Lariba \\ Department of Public Utilities Management, School of Management, Jiangsu University, \\ 301 Xuefu Road, Zhenjiang city, Jiangsu province 212013, China
}

\begin{abstract}
One of the fundamental issues in the educational sector in Tanzania is on how to increase and promote equipoise in education to the indigenous. The study encapsulates many of the central outcomes on educational policy change. It stipulates that, there are more children being enrolled in primary schools due to free education. This has consequently led educational sector to encounter encumbrance to the national budget either directly or indirectly. The impacts have mostly affected educational stakeholders including students, teachers, parents and policy implementers. This study is both quantitative and qualitative and was conducted in Nyamagana district. The study used population set to gather data from Mwanza region in Nyamagana District-Tanzania. The researcher limited himself to the respondents who were from Local Government Authorities that encompassed Education Officer of Mwanza Region, District Secretary Education as well as head teachers, teachers, students and parents who had children at primary schools.
\end{abstract}

Keywords: Implications, Policy, Education, Tanzania, Primary, School

DOI: $10.7176 / \mathrm{JEP} / 10-15-21$

Publication date:May $31^{\text {st }} 2019$

\section{I.Introduction}

(Haddad \& Demsky, 1995) defines policy as a functionally to entail: An explicit or implicit single decision or group of decisions which may set out directives for guiding future decisions, initiate or retard action, or guide implementation of previous decisions.

Prioritization of educational policy driven by manpower needs immediately followed independence, the Tanzanian government discerned 'ignorance' and illiteracy to be the obstacles that needed to be tackled through education. This meant to expand primary education. As a result access to primary education was connected to the notion of development and its provision began to preoccupy the Tanzanian government. As access to education had been problematic during colonial era, many Africans were simply denied the access to education (Oketch \& Rolleston, 2007). However, many who managed to enter primary education could not continue beyond four years of education because of the Standard IV examination system. Consequently, the government had to inaugurate strategies and initiatives to obviate challenges through the School Fees Abolition Initiatives (SFAI) as among the designed initiatives to significantly advance efforts to ensure access to quality primary education (Initiative, 2009).

Through the Tanzania Development Vision 2025 and the 2030 Agenda for Sustainable Development, also accord high precedence to the education sector to be pivotal in exceling social and economic transformation, as described in the following statement: Education should be treated as a strategic agent for mind-set transformation and for the creation of a well-educated nation, sufficiently equipped with the knowledge needed to competently and competitively solve the development challenges which face the Nation. In this light, the education system should be restructured and transformed qualitatively with a focus on promoting creativity and problems solving (URT 2000:19).

The Tanzania Development Vision 2025 states Tanzania's education vision as: “a well-educated, knowledgeable and skilled Tanzanian able to competently and competitively cope with political, social, cultural, economic and technological development challenges at national and international levels." In response to this, the Government attempts to provide equitable quality education and vocational skills to all. This requires adequate number of quality teachers, a conducive environment for stakeholders willing to participate in providing education delivery, and conducive learning/teaching environments for students and teachers at all levels.

Under goal four of the agenda is to ensure inclusive and equitable quality education and promote lifelong learning opportunities to primary education for all. That all nations including Tanzania has to ensure that all girls and boys complete free, equitable and quality primary and leading to relevant and effective learning outcomes.

Not only that, but also to build and upgrade educational facilities that are child, disability and gender sensitive and provide safe, non-violent, inclusive and effective learning environments for all. By 2030, substantially increase the supply of qualified teachers, including through international cooperation for teacher training in developing countries. 


\subsection{Problem of the study}

Free education policy entails School fee abolition that prompts ministry of education to engage in policy dialogue and consensus building with other sectors and development partners (Björkdahl \& Lundqvist, 2006). The abolishment of school fees has compelled the government to simultaneously replace lost revenue and deal with large boom in enrollment, creating financial encumbrance that is becoming hard to bear. This has necessitated to increase financial and technical support from development partners or official debt relief and financial contribution from non-governmental organizations (NGOs) and development agencies, a large proportion of which support school fee abolition. (Mugo, Kaburu, Limboro, \& Kimutai, 2011) highlighted that the school environment is another important feature of educational system to propel. Alongside household factors, differences in school conditions that can affect learning outcomes (i.e., academic performance) and are also more subject to improvement through changes in policies. Factors, including general infrastructure, such as electricity, clean water and toilets, and more specific pupil-oriented resources, such as school lunch programs and textbooks. Also number of teachers in schools as well as their degree of engagement, for which rates of teacher absenteeism from schools and teacher presence in classrooms. The adequate availability of toilets is measured by the Pupil Pit Latrine Ratio (PLR). In Primary schools the PLR is currently 53:1 and 50:1 for boys and girls respectively.

\subsection{Primary school challenges}

The greatest challenge is the construction of adequate classrooms in Primary schools in order to meet the new curriculum's target of 40 pupils per class in Primary schools, assuming single use of each classroom per day. (The United Republic of Tanzania, 2018) there is a current need for 314,105 Primary classrooms in Government schools, representing a deficit of 262,506 classrooms. However, by introducing double shifts from Pre-Primary to Standard IV and setting an interim maximum class size of 60 , the immediate need for new classrooms is reduced to 44,982 (Primary Teacher Deployment Strategy, 2017). Also the teacher-pupil ratio at primary schools in Tanzania remains high at 1:43, higher than the sub-Saharan average and the number is commonly referred to as the international standard of 1:40. At pre-primary level (Vranken, Smits, \& Jong, 2011) says this ratio reaches 1:169, within Local Government Authorities' discretion. Therefore, the real responsibilities of Local Government Authorities in shaping the education sector is small and unrepresented by the size of the budget they manage. According to the national Primary education curricula, one classroom is supposed to be shared simultaneously by not more than 45 pupils in Primary schools. For stance, the number of classrooms in primary schools increased from 115,560 in 2010 to 128,479 in 2017, while the number of pupils per classroom remained unchanged from 73 pupils in 2010 to 73 pupils in 2017, although this ratio had reduced marginally to 72 in 2015 . This was due to increased enrolment rate from 2004 to 2009 that is attributed to the implementation of the Primary Education Development Plan (PEDP) I and II which promoted access to education especially for children in rural areas. The possible explanation for the decrease of the enrolment from 2010 to 2014 might be due to the increased dropout rate led by truancy which was $75.5 \%$ in 2012. The sharp increase in enrolment in 2016 and 2017 are almost certainly due to the Fee-Free Basic Education policy (The United Republic of Tanzania, 2018).

Purpose of the study

The focal point of this study is to bridge the gap between policy change and the effects on cost for children enrollment, human resources, school infrastructures, teacher's salary and learner's performance. This paper also intends to fill the gap by investigating the effective programs, initiatives and their characteristics on cost relief to school children enrollment. 
Table 1: Research questions guided the study

\begin{tabular}{|c|c|}
\hline$\bullet$ & Since the abolishment of school fees has there been changes in primary education sector? \\
\hline$\bullet$ & Are there measures against parents who violate the law of not enrolling children? \\
\hline & Has the rate of primary school student's dropout decreased within five years? \\
\hline$\bullet$ & Is there any international organization supporting education in Tanzania? \\
\hline$\bullet$ & Has the current educational policy brought great changes in primary education? \\
\hline$\bullet$ & Are there capitation and grants for school materials and other charges? \\
\hline & Do capitation and grants arrive on time for primary schools? \\
\hline & $\begin{array}{l}\text { Do capitation and grants for teaching and learning/ materials fulfill fully the educational needs for } \\
\text { children? }\end{array}$ \\
\hline & Do students get free uniform and meal program at school from the government? \\
\hline & Are there any changes in enrollment between boys and girls in the last five years? \\
\hline & Do students have enough space for sports and games? \\
\hline & Does the school have adequate safe and clean water, hygienic toilets with flash nature? \\
\hline & $\begin{array}{l}\text { What is the student's class ratio at school? Does this ratio exceed than the capacity of the class to carry } \\
\text { the required number of students? }\end{array}$ \\
\hline & If there are incentives or money from the government do they arrive on time? \\
\hline & Does the physical environments favor them students with disability? \\
\hline & Is the curriculum in Tanzania suitable for all students or there is a need for changes? \\
\hline & Do school inspectors often pay visit to schools? \\
\hline & Are all students able to wear quality school uniform? \\
\hline & Having students with disability, does the physical infrastructure favor them? \\
\hline & Are teachers being given accommodation, overworked and receive their salary on time? \\
\hline & If teachers are being given accommodation are they comfortable with it? \\
\hline & Do all the teaching and learning facilities required to teach pupils available at school? \\
\hline & Has the teacher-student ratio changed and what are the reasons for change? \\
\hline & Has the teacher's salary changed in any direction for the last couple of four years? \\
\hline & Has the abolishment of school fees affected teacher's salaries? In which way? \\
\hline & Has the quality of education changed? \\
\hline & What is the important thing for improving the quality of education? \\
\hline & Has the teacher recruitment been able to keep up with the increased enrollment of pupils? \\
\hline & Has the burden to teachers increased due to high number of students? \\
\hline & Is the performance children in mathematics good? For class 1,2 and 3 \\
\hline & Are all children able to read and write on time? For class 2 and 3 \\
\hline & Are there still any challenges when sending a child to school? \\
\hline & Do parents consider education to be important to their children? \\
\hline & Do parents pay any fee for their children before being enrolled to school? \\
\hline & Are both girls and boys have equal access to education? \\
\hline & Is there corporal punishment for students being given? \\
\hline & Does it take long time for a student to reach school? \\
\hline
\end{tabular}

\section{Materials and methods}

\subsection{The reasons for increased enrollment}

The increase in enrolment prior to 2016 was due to the implementation and enforcement of the education policy that required every school to have a Pre-Primary class. The increase was promoted by the Fee-Free Basic Education policy. (The United Republic of Tanzania, 2018) and decreased rate of corruption. It is stated that, policies that decrease corruption make sure more money from the original amount can be spend on education, without money being lost to all kind of corrupt government officials or organization (Vranken et al., 2011). Hence the size of government consumption which include salaries is then correlated with corruption. This implies that reducing civil sector employment could act as form of fighting corruption. In that case there is a positive effect on children's enrollment at schools.

However, there is a need to do further study on the reasons for the dip in enrolment in the years 2012 and 2013. On average, enrolment was increasing at the rate of 2.7 percent (\%) per year over the period of twelve years (2004 - 2015), followed by a sudden jump in 2016. Overall, enrolment increased from 554,835 in 2004 to $1,517,670$ in 2017 , which is equal to a 173.5 percent (\%) increase. However, the government has come to recognize 
that school fee abolition alone is not enough to attract the poor students or parents and the marginalized people (Björkdahl \& Lundqvist, 2006).

(Vranken et al., 2011) argues that, the influence of school enrollment at the district level are due to the level of development and urbanization. That is the higher the level of development (such as better infrastructure, more job opportunities and better health care), the increase of the quality of living in the district, which in turn affects school enrollment positively (Filmer \& Pritchett, 2001). This higher level of development is more likely to be found in urban districts, where often better road and transport infrastructures, firm state influence have and better educational opportunity(Fafchamps \& Wahba, 2006) (Fafchamps \& Wahba, 2006; Huisman \& Smits, 2009). Growth in school enrollment at the district level is also expected to depend the average household size, the average number of children under 5 per household, and the average educational level of adults at the district level (Buchmann \& Hannum, 2001).

\subsection{Cost implications associated with abolition of school fees and increased enrollment}

Over a decade after the rollout of free and mandatory education, approximately 8.5 million children are enrolled in six years of primary education, representing close to 77 percent (\%) of children of primary school going age (Human Rights Watch, 2017). As free education policy exempt children or parents to paying school fees and other school expenses (UK aid, 2018), the government has spent and will spend more in education. For stance in 2015, seventeen (17) percent (\%) of expenditure in low income countries and sixteen (16) percent (\%) in lower middle income countries spent to education a large share of public resources. Yet many countries including Tanzania fall short of targets for public financing of education set in the Education 2030 Framework for Action. To achieve global education targets it is estimated that developing countries will need to increase annual public expenditure from $\$ 1$ trillion in 2015 to \$2.7 trillion in 2030 (from 4 to 5.8\% of Gross Domestic Product), alongside international and private sector investment. Apparently, President's Office Regional Administration and Local Government (PORALG) has oversighted of almost all recurrent expenditures are dedicated to primary education on the Tanzania Mainland. So, the increased education spending has negative significant effects for girls and boys aged 12-14 (Vranken et al., 2011). As the lion's share of education expenditure goes towards recurrent spending, it amounts to 76 per cent (\%) of the total education budget. However, this share has been decreased and fell from 84 per cent (\%) in Fiscal Year 2015/2016. Meanwhile, in Fiscal Year 2017/2018 Tanzania trailed the average for emerging and developing countries in terms of Gross Domestic Product (GDP) dedicated towards education. At 3.9 per cent (\%) of total Gross Domestic Product (GDP) went towards education, the country was 0.6 below the average. The share of the government's total budget directed to education is 14.8 per cent (\%) (Unicef, 2018) which included student loans and infrastructural investments. Notwithstanding that the share of development budget in total remained small, it has entered a growth path (an increase of 8 per cent $(\%)$ in the Fiscal Year $2017 / 2018$ budget and of 65 per cent (\%) in the Fiscal Year 2016/2017. The increase in the development expenditure was driven by the growing amount of development funds available to Local Government Authorities. Local Government Authorities and council level institutions, allocate funds in accordance with national policies, established by the Sectoral Ministries. They mainly receive their revenue in a form of basket funds including primary education. The education basket for Local Government Authorities makes up the largest share of Local Government Authorities budget. Despite their devolved responsibility, Local Government Authorities remain mostly administrators of recurrent expenditures (generally salaries). In Fiscal Year 2017/2018 salaries consumed 94 per cent $(\%)$ of the funds allocated to education baskets, leaving little room for development expenditures standing at under TSh50,000 (21.69\$) a year (Unicef, 2018).

\section{Methodology and sample 3.1 Target population}

The target population considered teachers, parents, students and government officials. Prior to the population consideration and choice, there was a preliminary study on the topic which was carried out and the results revealed that conditions prevailing in all the locations in the district were similar. As a result, there is a likelihood that, there is the cost implications of primary school educational policy shift to free education provision for primary school children in the district.

\subsection{Sample and sampling procedures}

This study used population set to collect data from Mwanza region in Nyamagana District-Tanzania. The researcher limited himself to the respondents who were from the Local Government authorities that included Education Officer of Mwanza Region, District Secretary Education of Nyamagana District, head teacher, teachers and students from three schools namely Buhongwa "A" primary school, Nyamahango primary school and Mkuyuni primary school as well as parents who had children at primary schools. 
Table 2: Research Participants distribution

\begin{tabular}{|l|l|l|}
\hline Respondent(s) & $\begin{array}{l}\text { Office/school/district } \\
\text { Region/ }\end{array}$ & Respondent's number \\
\hline Education officer & Mwanza Region & 1 \\
\hline District Secretary Education & Nyamagana District & 1 \\
\hline Head teacher(s) & Buhongw “A" Primary School & 1 \\
\hline \multirow{3}{*}{ Teachers } & Buhongwa “A" Primary School & 12 \\
\cline { 2 - 3 } & Mkuyuni Primary School & 12 \\
\cline { 2 - 3 } & Nyamahango Primary School & 12 \\
\hline \multirow{3}{*}{ Pupils } & Buhongwa "A" Primary School & 17 \\
\cline { 2 - 3 } & Nyamahango Primary School & 16 \\
\cline { 2 - 3 } & Mkuyuni Primary School & 17 \\
\hline Parents & Nyamagana District & 22 \\
\hline \multicolumn{2}{|l}{} & 111 \\
\hline
\end{tabular}

Regional Education Officer and District Secretary education were selected due to their significant contribution in monitoring primary education policy. Teachers were considered because they are the implementers of education policy. Their opinions are of more significant when it comes to what should be modified in the curriculum accordingly to suit children's needs.

\subsection{Data and data collection technique}

The researcher applied interviews, observation and documentary review techniques to collect data. (Subbiah, 2009) quoting (Watanabe \& RS) asserts that: "each type and source of data has strengths and weaknesses. Combining data type's increases validity as the strengths of one approach can compensate the weaknesses of another approach". The process of combining different ways in assembling information is called triangulation (Silverman, 2005; Subbiah, 2009). (Subbiah, 2009) points out "qualitative interviewing begins with the assumption that the perspective of others is meaningful, knowledgeable, and able to be made explicit". In doing so, the researcher is in position of discovering new insights that gives opportunity to his / her clients to speak. "The quality of the information obtained during an interview depends on the interviewer"(Subbiah, 2009). The purpose of interviewing is for knowledge acquisition from interviewee point of views. Interviews can either be structured or semi-semi structured; or open (unstructured) interviews. In other words the interview guide provides topics or subject areas within which the interviewer is free to explore, probe, and ask questions ..." (Subbiah, 2009)). Documentary reviews was also carried out in already published journal, articles, books and research. The source comes from the President's Office Regional Administration and Local Government 2017 and 2018. Also the use of primary source in social research (Long \& Johnson, 2000), is essential in acquiring information. A document is any written or recorded material which is not prepared for the purpose of the inquirer(Lincoln \& Guba, 1985).

Table 2: Collection technique description

\begin{tabular}{|l|l|l|}
\hline Technique & Participant/Activity & Data \\
\hline Interview & Government officials & $\begin{array}{l}\text { Quality of education, other sources to support education, education } \\
\text { policy impacts, strict measures for pupils not attending school }\end{array}$ \\
\cline { 2 - 3 } & $\begin{array}{l}\text { Head teacher and } \\
\text { Teachers }\end{array}$ & $\begin{array}{l}\text { Capitation grants for teaching and learning materials, free meal } \\
\text { programs, change in enrollment rate, pupil's class ratio, pupil- } \\
\text { teacher ratio, book-pupil ratio, toilets, salary, accommodation, } \\
\text { school budget and effects of abolition of school fees. }\end{array}$ \\
\cline { 2 - 3 } & Pupils & $\begin{array}{l}\text { School fees, basic needs, distance from home to school, lack of } \\
\text { uniform, corporal punishment, opinion, basic needs } \\
\text { Schooling mood. }\end{array}$ \\
\cline { 2 - 3 } & Parents & $\begin{array}{l}\text { Education perception, school fees payment, importance of education, } \\
\text { challenges in sending children to school, ability of the child to read } \\
\text { and write, performance in mathematics or numerals }\end{array}$ \\
\hline Observation & Observing & $\begin{array}{l}\text { Teaching and learning process, class structure, student's } \\
\text { participation, class and school infrastructures. }\end{array}$ \\
\hline
\end{tabular}

\subsection{Data analysis}

Both quantitative and qualitative methods were used in data analysis. Although quantitative and qualitative research apply Validity and reliability, they are addressed differently (Ahlrichs, Furche, \& Grimme, 2000; BrockUtne, 1996). According to (Silverman, 2005) "validity is another name for truth". As it is not possible to have pure valid research, quantitative researchers make effort to improve validity through careful sampling, appropriate instrumentation and appropriate statistical treatment of the data (Pillon \& Pesenti, 2001). 
Under quantitative there was the use of SPSS package software to analyze the questionnaires to pinpoint the cost implications of primary school educational policy on free education for primary school children. Qualitative data analysis is "working with data, organizing it, and breaking into manageable units, synthesizing it searching for patterns, discovery what is important and what is to be learned, and deciding what you will tell others"(Putri; Van Wyk, 1996).

\section{Results and discussion}

The critical aspect of the learning environment is the degree of engagement of the students themselves, which is partially evident by rates of school attendance. A preliminary question in relation to the school environment is whether conditions vary systematically across schools in different regions, i.e., to what extent do children in one region face similar schooling conditions, regardless of the specific school they attend. To examine school conditions, the current analysis uses school level data from the 2015 Uwezo survey to determine the average conditions in government (public) primary schools in Tanzania (Uwezo, 2017).

Findings of the research reveals government estimates that seventy four (74) percent (\%) of all Tanzanian children live in "multidimensional poverty," and that twenty nine (29) percent (\%) live in households below the monetary poverty line. Notwithstanding this life condition, efforts have been done to increase children enrollment to primary schools. For example, there has been an increased enrollment from 9.6 percent (\%) in 2012 to 18.5 percent (\%) in 2017 of children who are below seven (7) years old.

According to Mwanza Region Education Officer stated that, "The abolition of school fees has resulted to mass enrollment leading to inadequacy of existing resources like classes, human resources (teachers), books, desks and chairs. But the positive thing is through the current educational policy, it has favored all individuals with different economic background to equally access education hence reducing street children, child labor in Nyamagana and at national level." Tracing back in 2008 and 2012, primary school net attendance among the poorest twenty (20) percent (\%) of the population was 67.5 percent $(\%)$, compared with 98 percent (\%) across the entire primary school aged population. So, even after the abolition of school fees, still cost of smaller items such as uniforms, learning material, or food keeps many of the poorest students at bay from accessing free and quality primary education. For stance among of twenty two (22) parents 63.6 percent (\%) of the respondents said bear the cost for enrollment, 27.3 percent $(\%)$ said no and 9.1 percent $(\%)$ they somehow bear the cost. Hence parents, relatives or guardians with low income are sometimes unable to pay such costs. Many children from the poorest households are exposed to the harsh consequences of economic disparities, which invariably impact on their education. This is contributed by many families do not have access to additional social protection funding to cover education costs. The impact comes when lack of motivation as 27.3 percent (\%) of respondents said have had challenges to send their children to school, while 45.5 percent (\%) had no problem but 27.3 percent (\%) somehow experienced challenges. Because of the government not adopting a short to medium term plan to ensure vulnerable children can stay in school, there has been a lack of motivation for parents to send their children to school. Lack of financial support for poor families with children would lead the parents to devalue the importance of education. For example 54.5 percent (\%) said they would like their children to attend school on regular basis, while 36.4 percent $(\%)$ said no need for their children to attend and 9.1 percent $(\%)$ perceived somehow education is good. But still the same number of population sample 77.3 percent $(\%)$ proved to say education is important to their children while 13.6 percent (\%) said somehow and the rest of 9.1 percent (\%) said education is of no importance.

Economic hardship and high deprivation rates make many parents influence their children into child labor often in exploitative, abusive, or hazardous conditions including in gold mines, fisheries, farms, or in domestic work. Many of these conditions are in violation of Tanzanian law. Overall, 4.2 million or 29 percent (\%) of children aged 5-17 engage in child labor. Among the most vulnerable children are an estimated 3 million orphans, of whom roughly 1.2 million have lost a parent due to Human Immunodeficiency Virus/Acquired Immunodeficiency Syndrome (HIV/AIDS).

The District Secretary education had her own views as quoted saying, "Since the abolishment of school fees in Tanzania, the rate of number of pupils has increased. This indicates that our education system is growing especially when we are focusing on making sure that all individuals are able to read and write".

However the challenges comes when some of the students jump to the next class without mastery of skills in numeracy, writing and reading. As for example among the 22 parents who had their children at school only 22.7 percent $(\%)$ of their children are able to master numeracy at the first grade, 50 percent $(\%)$ said no and 27.3 percent (\%) said somehow their children can master mathematics. On reading and writing 40.9 percent $(\%)$ of the respondents said their children were able to read and write at first grade or standard one while 50 percent (\%) said no and 9.1 percent (\%) their children can somehow read and write.

As Tanzania's 2014 Education and Training policy, officially launched in February 2015 declared 10 years of free and compulsory basic education: six years of primary education. This has shown great change as $100 \%$ of pupils who were interviewed said have never been sent back home because of not paying school fees. So under this policy, children enrolled in the first year of primary education in 2016 went through 10 years of fully free and 
compulsory basic education. Notwithstanding the success of total removal of school fees, $16.0 \%$ of pupils said have ever been sent home due to lack of proper uniform and other contribution like money for desks and chairs. $80 \%$ said they have not been sent home due to lack of uniform and school contribution.

In maintaining similar levels of education spending since 2010, Tanzanian government has to spend at least 20 percent (\%) of total national budgets on education. Among thirty six (36) teachers interviewed for example, seventeen (17) teachers that is 47.2 percent (\%) approved to say there has been a positive change for the school budget. But 36.1 percent (\%) respondents said there is no any positive change in the school budget. Having in 2015-2016 Tanzania spent slightly over 16 percent (\%) of its national budget on education as well as in 20162017 , it only allocated 22 percent (\%) of its total national budget to education. Most of the government's education budget covered capital and recurrent expenditures, including teachers' and civil servants' salaries. This has impact on teacher's salary as they are to be deducted in their monthly salary for tax due to abolition of school fees for students. It has affected teachers indirectly as $30.6 \%$ of teachers interviewed said have to pay more tax to the government.

In the Fiscal year 2017/2018 budget the government allocated TSh4.71 trillion for education expenditure. It marks a decline of TSh63.99 billion (1.3 per cent) compared to the previous budget. It has affected teachers and schools in general as 31.1 percent (\%) of the interviewee said had financial resources for school materials while 33.3 percent (\%) had inadequate financial resources. When considering that inflation is close to 5 percent (\%), and the number of enrolled students has grown exponentially, the decline in available resources becomes even more apparent. For stance on teaching and learning facilities 55.6 percent (\%) of respondents approved to have inadequate school facilities. In the budget, 76 per cent (\%) is planned for recurrent expenditure - mostly wages and 24 per cent for development. Under current regulations, any parent or guardian who fails to ensure a child is enrolled in primary school commits an offence, and may be liable to a fine or imprisonment of up to six months. Under the Law of the Child Act, children have a right to education, including a right to acquire vocational skills and training, and parents have a duty to ensure children can realize this right. According to Education Officer of Mwanza region stated that, "Parents who are found guilty by the law by not sending their children to school are punished accordingly". It is also stated in Tanzania's Education Act that, all children above the age of seven must attend and complete compulsory primary education.

According to interview conducted to primary teachers in Nyamagana district, only 16.7 percent (\%) among the teachers said they like their professional, 30.6 percent (\%) said they don't like while 52.8 percent (\%) somehow love teaching. Given the already existing scarcity of adequately prepared teachers, especially in the primary schools, the extra enrolment will likely decrease pupils teacher ratio. The average number of students is increasing. For stance 83.3 percent (\%) of respondents said they teach more than forty five (45) students in the class diminishing teaching and learning standard. As more and more children being enrolled, the more the burden to the teachers increases. Yet, they added 77.8 percent (\%) of teachers also agreed to say that, because of abolition of school fees many pupils are being enrolled leading to overcrowding the class. Considering quality of education only 25 percent (\%) said the quality of education had improved, 33.3 percent (\%) said there is no change and 41.7 percent (\%) said there is a little change.

In Tanzania, according to the 2005 curriculum, the standard Pupil Teacher Ratio (PTR-Number of Pupils: 1 Teacher) is 25:1 for Pre-Primary education and 45:1 for Primary education. It needs to be noted that, although the Government has made efforts to tackle the problem and in 2016/2017 it provided training to 17,650 teachers. In 2017/2018 the Government committed to the training of 45,000 teachers on early primary literacy and numeracy. However when these teachers are being posted to their teaching centers, face accommodation as teacher's houses are inadequate. Among 36 teachers interviewed, only four teachers making 11.1 percent $(\%)$ have accommodation but 75 percent (\%) proved that they are not comfortable to live in those houses. 
Table 3: Teachers opinion on free education policy outcomes

\begin{tabular}{|l|l|l|}
\hline Questions & Frequency & Percent (\%) \\
\hline Feeling to be overworked & 12 & 33.3 \\
\hline Do not receive salary on time & 4 & 11.1 \\
\hline No accommodation & 30 & 83.3 \\
\hline No or inadequate teaching/learning materials & 20 & 55.6 \\
\hline One teacher teaches more than 45 students & 30 & 83.3 \\
\hline Pupil-Teacher ratio is constant within five years & 28 & 77.8 \\
\hline Less mutual interaction between teachers/pupils & 15 & 47.2 \\
\hline Student council is inactive & 12 & 33.3 \\
\hline Positive change in school budget & 13 & 36.1 \\
\hline Less financial resources for school materials & 12 & 33.3 \\
\hline Effect of abolition of school fees on salary & 11 & 30.6 \\
\hline Education quality has not changed & 12 & 33.3 \\
\hline Corporal punishment is good & 15 & 41.7 \\
\hline Increased pupils led to teaching burden increase & 24 & 66.7 \\
\hline
\end{tabular}

Table 4: Students opinions on free education policy outcomes

\begin{tabular}{|l|l|l|}
\hline Opinion & Frequency & Percent $(\%)$ \\
\hline Somehow able to say my views & 3 & 6.0 \\
\hline Somehow able to get basic needs & 4 & 8.0 \\
\hline Disappointed with corporal punishment & 4 & 8.0 \\
\hline Takes long time to reach school & 15 & 30.0 \\
\hline Teachers do not attend class on time & 2 & 4.0 \\
\hline Going to school is not interesting & 1 & 2.0 \\
\hline Sometimes hate going to school & 6 & 12.0 \\
\hline Have ever been sent home due to lack of fees & 50 & 100.0 \\
\hline Sent home for improper uniform \& other contribution & 8 & 16.0 \\
\hline
\end{tabular}

Table 5: Parents opinions on free education policy outcomes

\begin{tabular}{|l|l|l|}
\hline Opinions & Frequency & Percent (\%) \\
\hline My child(ren) perform poorly in mathematics & 11 & 50.0 \\
\hline Performance is somehow better in mathematics & 6 & 27.3 \\
\hline Children do not read on time & 11 & 50.0 \\
\hline There is a challenge to send a child to school & 10 & 45.5 \\
\hline Education has no importance & 2 & 9.1 \\
\hline I pay enrollment fee & 14 & 63.6 \\
\hline
\end{tabular}

\section{Discussion}

While gender parity has been achieved at primary level, at higher levels the percentage of enrolled girls drops dramatically. The overall decline in enrolment is predominantly a consequence of monetary and opportunity costs which increase with age, while the gender disparity is a consequence of the general, perceived role of women in the society. Example among the people interviewed on whether boys and girls have equal access to education, 72.2 percent $(\%)$ agreed while 13.6 percent (\%) said no. Children from rural areas are also much less likely to attend school than those in urban areas. One of the most often listed reasons for not attending or leaving school is perceived lack of benefits of attending school, not the cost (which however remains important).

Adequate and sustainable accommodation for teaching and non-teaching staff in the education sector is an important factor for education performance in both urban and rural areas where suitable accommodation is not generally available in the vicinity of schools. Among the teachers being interviewed, only 11.1 percent (\%) had accommodation. Hence for the prosperity of education, availability of teacher's housing is one of the motivating factors for teachers. As the study shows 83 percent (\%) of teachers travel for long distance to school as they are not provided with school accommodation. However, 75 percent (\%) for the teachers see school accommodation are below the standard to live in those houses. This is also verified by Education and Training Policy (ETP) 2014 declares that in recent years there has been a big shortage of teachers' houses. This affects teacher's mood of teaching and students prosperity.

More financial support to education is vital for improved access, equity and quality achievement in the implementation of education programs. Being education as a central factor in the economic growth of a nation, it 
has great influences in equipping skills and mind-sets of the people in a given society. Thus, financing education is an essential prerequisite for economic growth. According to this study 98 percent (\%) students said going to school is interesting to them although sometimes they face some challenges that keep them away to like studying. Some of the challenges include long distance and time to school as there is no school bus and corporal punishment once they arrive at school late. For stance 30 percent $(\%)$ travel for long distance almost from one hour to two hours and if they are late, they are caned with sticks although 88 percent (\%) feel okay with the punishment, 8 percent (\%) feel to be disappointed and 4 percent (\%) said they feel somehow disappointed. Sometimes because of the school environment being not friendly and motivating, they feel like to hate going to school. 12 percent (\%) said they sometimes hate going to school although 98 percent $(\%)$ see schooling is interesting and would like to attend school every day if the challenges mentioned are to be solved.

However, as one of the world's largest young populations under the age of 25, and 43 percent (\%) of its population under 15, Tanzania, a low-income country, faces enormous challenges in guaranteeing basic education for all. Out of the 5.1 million children who are not in basic education, almost two million, or one in every five children, are not in primary school (Human Rights Watch, 2017). Even in countries where overall enrolment is high, significant number for children leave school early. In fact, among the world's 650 million children of primary school age, 130 million are not learning the basics of reading, writing and arithmetic(Orodho, 2014).

\section{Conclusion}

Quality education in Tanzania is still and will remain volatile than its peer countries if the addressed challenges are not fully tackled. According to literature review vindicates that, policies to alleviate corruption rate facilitates the increase of children enrollment at primary schools. Outcomes are more beneficial for children of the disadvantaged social groups. Removal of enrollment costs has a significant impacts for children to access school. Increase in net national budget reserve and proper allocation of funds prove to have significant increase in enrollment of children at primary school.

\section{Recommendation}

This study commends that, for to maintain a well-educated nation, education should be strategically treated as a blue print for the mind set transformation, sufficiently to equip people with knowledge and skills to absolutely and competitively alleviate education obstacles which face the country. Vitally, the education system has to be restructured and transformed qualitatively to focus on encouraging creativity and problem solving.

\section{Acknowledgement}

I would like to sincerely express my gratitude to Professor Chen Yinghua from Jiangsu University for her moral and material support without forgetting my mother Martha Mussa, for her financial support on data collection during this study.

\section{References}

Ahlrichs, R., Furche, F., \& Grimme, S. (2000). Comment on "Assessment of exchange correlation functionals" [AJ Cohen, NC Handy, Chem. Phys. Lett. 316 (2000) 160-166]. Chemical Physics Letters, 325(1-3), 317-321.

Björkdahl, E., \& Lundqvist, P. (2006). The abolishment of school fees in Tanzania: A case study of the quality of education. Unpublished Masters Thesis, Goteborgs University, Goteborgs.

Brock-Utne, B. (1996). Reliability and validity in qualitative research within education in Africa. International review of education, 42(6), 605-621.

Buchmann, C., \& Hannum, E. (2001). Education and stratification in developing countries: A review of theories and research. Annual review of sociology, 27(1), 77-102.

Fafchamps, M., \& Wahba, J. (2006). Child labor, urban proximity, and household composition. Journal of development Economics, 79(2), 374-397.

Filmer, D., \& Pritchett, L. H. (2001). Estimating wealth effects without expenditure data-or tears: an application to educational enrollments in states of India. Demography, 38(1), 115-132.

Haddad, W. D., \& Demsky, T. (1995). Education Policy-Planning Process: An Applied Framework. Fundamentals of Educational Planning 51: ERIC.

Human Rights Watch (2017). [I Had a Dream to Finish School" Barriers to Secondary Secondary Education in Tanzania].

Initiative, S. F. A. (2009). Six Steps to Abolishing Primary School Fees: Operational Guide: World Bank, UNICEF. Lincoln, Y. S., \& Guba, E. G. (1985). Effective evaluation. New York: Jassey-Bass.

Long, T., \& Johnson, M. (2000). Rigour, reliability and validity in qualitative research. Clinical effectiveness in nursing, 4(1), 30-37.

Oketch, M. O., \& Rolleston, C. M. (2007). Policies on free primary and secondary education in East Africa: A review of the literature. 
Orodho, J. A. (2014). Policies on free primary and secondary education in East Africa: Are Kenya and Tanzania on course to attain Education for All (EFA) Goals by 2015. International Organization of Scientific Research (IOSR) Journal of Humanities and Social Sciences (IOSR-JHSS), 19, 11-20.

Pillon, A., \& Pesenti, M. (2001). Calculating without reading? Comments on Cohen and Dehaene (2000). Cognitive Neuropsychology, 18(3), 275-284.

Putri, N. L. Teaching Reading to Children Ages 7-8 Years to Early Light Tunagrahita and Their Difficulties Following the Inclusive Primary School.

Silverman, D. (2005). The Methodology Chapter. Doing Qualitative Research, 2, 302-309.

Subbiah, C. (2009). The role of learners in the management of discipline in urban secondary schools in KwazuluNatal.

The United Republic of Tanzania. (2018). Basic Education Statistical Abstract 2004-2017. Tanzania.

Unicef. (2018). Education Budget Brief 2018. Tanzania.

Uwezo. (2017). Are our children learning? Uwezo Tanzania Sixth Learning Assessment Report. Dar es Salaam: Government.

Van Wyk, J. N. (1996). Parent involvement in black urban communities in Gauteng.

Vranken, M., Smits, J. P. J. M., \& Jong, E. d. (2011). Effects of IMF programs on school enrollment in developing countries.

Watanabe, K., \& RS, R. An Investigation on the Effectiveness of "Dolphin Encounter for Special Children"(DESC) Program for Children with Autism Spectrum Disorders. 